\title{
United Nations "Policy": An Argument with Three Illustrations
}

\author{
RAMESH THAKUR \\ Centre for International Governance Innovation \\ THOMAS G. WEISS \\ The Graduate Center, The City University of New York ${ }^{* *}$
}

\begin{abstract}
This article explores whether and in what sense there is a "United Nations policy," a topic unexplored in the literature. The UN's universal character provides legitimacy, a precious asset in formulating global public policy. It is thus the forum of choice for regime negotiation and norm promotion for contested contemporary challenges, reflecting its comparative advantage and its unique ability to formulate policies that aspire to universal application and relevance. This essay explores the UN's particular contribution to global problem-solving for terrorism, sustainability, and controlling pandemics in order to show, through these three illustrations, how the United Nations contributes to the advance or retreat of global governance.
\end{abstract}

Keywords: United Nations, global governance, policy studies, terrorism, sustainability, health

When post-war Iraq requested UN assistance for training Iraqi judges and prosecutors who would be trying Saddam Hussein and his senior associates, the response from UN Secretary-General Kofi Annan was that the organization would not assist national courts

\footnotetext{
** Authors' note: This article draws on a draft of our forthcoming book, The United Nations and Global Governance: An Unfinished Journey (Bloomington: Indiana University Press, 2009). We would like to acknowledge the exceptional research and editorial assistance of Anoulak Kittikhoun. We also benefitted from critical comments by Louis Emmerij, Richard Jolly, and Craig Murphy and by two anonymous reviewers.
} 
that can impose the death penalty (Simons, 2004). Similarly, in his report on transitional justice, he again affirmed that the United Nations would not establish or participate "in any tribunal for which capital punishment is included among possible sanctions” (Annan, 2004: Para. 64d). ${ }^{1}$ But whose preferred political morality is this? What proportion of the world's people live under governments that have capital punishment on their statutes, including China, India, Indonesia, and the United States? Who sets the relevant international standards and benchmarks? Does the United Nations somehow have a state of grace above its member states? Most pertinently for present purposes, what does this say about "UN policy” as such? It could be argued that UN policy is to oppose the death penalty, and that the refusal to provide technical assistance that could result in the death sentence being imposed was implementation of the policy. But equally, it could be argued that opposition to capital punishment is a global norm and a refusal to provide training that could lead to the death penalty was the expression of that norm.

As is further defined below, "policy” refers to the statement of principles and actions that an organization is likely to pursue in the event of particular contingencies. It is in this sense, for example, that we are given copies of our insurance "policy" documents for our house and cars. Thus, the UN policy might be to promote awareness

\footnotetext{
${ }^{1}$ As in national decision-making, the Secretary-General would seek and receive advice from a variety and range of sources: the different relevant departments in the Secretariat in New York, in this case including but not limited to the Office of Legal Affairs, the Department of Political Affairs, the Executive Office of the Secretary-General, which includes the Strategic Planning Unit; from trusted individual advisers, including in particular those in the Executive Office and the Deputy Secretary-General (Louise Frechette) and the Chef de Cabinet (Iqbal Riza); and interested and concerned UN entities and officials outside the Secretariat drawn from the global UN system, including but not limited to the Geneva-based High Commissioner for Human Rights and, especially, the Special Representative of the Secretary-General for Iraq. Again as in national systems, each bureaucratic unit would also involve a number of sub-units and individuals in drawing up its briefs and recommendations. The various briefs and points of view would be submitted to executive committees that group cognate departments, like the executive Committee on Peace and Security, as well as the Secretary-General's "cabinet." The extensive consultative process notwithstanding, on any significant policy issue the final decision was very much that of Kofi Annan. This description is based on the personal experience of one of the co-authors who worked directly with Kofi Annan as the principal writer of his second reform report in 2002.
} 
about the gravity and causes of HIV/AIDS, encourage educational campaigns by member governments, reject participation by HIV-positive personnel in UN operations, and declare zero tolerance of sexual exploitation by UN peacekeepers.

Policy needs to be distinguished both from norms and institutions. A norm can be defined statistically to mean the pattern of behavior that is most common or usual—or the “normal curve” that represents a widely prevalent pattern of behavior. Alternatively, it can be defined ethically to mean a pattern of behavior that should be followed in accordance with a given value system, the moral code of a society, or a generally accepted standard of proper behavior. In some instances, the two meanings may converge in practice; in other cases, they diverge; but for most of the time, they will complement each other. In the Ottawa Treaty banning landmines, norm generation by Western middle powers was underpinned by norm-advocacy from nongovernmental organizations (NGOs) and reinforced by norm-promoting standard-setting by the UN Secretary-General when he endorsed the Ottawa process as the negotiating track and the convention that resulted from it (Hubert, 2000; Price, 1998; Thakur and Maley, 1999). A relatively recent effort at UN norm-building was the Global Compact that grew from the 2000 Millennium Summit (Ruggie, 2001, 2007).

With growing awareness that a new problem is serious enough to warrant attention by the international policy community of states, new norms in which the newly acquired knowledge is embedded need to be articulated, disseminated, and institutionalized. For example, once we know that HIV/AIDS is transmitted through unprotected promiscuous sexual activity, the norm of safe sex follows logically. As a universal organization, the United Nations is an ideal forum to seek consensus about 
normative approaches that govern global problems and would work best with a worldwide application of a norm. The host of problems ranging from reducing acid rain to impeding money laundering to halting pandemics clearly provide instances for which universal norms and approaches are emerging. At the same time, the UN can be a frustrating forum because dissent by powerful states or even coalitions of less powerful ones means either no action, or agreement only on a lowest common denominator. A particularly good illustration of this is the difficulty in operationalizing the norm for each individual state has the "responsibility to protect its populations from genocide, war crimes, ethnic cleansing and crimes against humanity” as agreed to by heads of government meeting at the 2005 World Summit (Thakur, 2006; Weiss, 2007).

If policy is to escape the trap of being ad hoc, episodic, judgmental, and idiosyncratic, it must be housed within an institutional context. ${ }^{2}$ If there is a relatively well-known problem or a range of agreed-upon policy, what is the machinery that will put such a policy into effect? For example, one may have determined that democratic states are less likely to go to war with one another and that increasing their numbers is valuable, and hence a policy could be announced to hold elections after peace has broken out in a protracted armed conflict. However, this has little meaning unless there are also institutions such as a local election commission along with outside observers to register voters and to arrange for poll workers, polling stations, printing of ballots, verification of rolls, and tallying of results. Institutions that are most effective often are those that deal with well-known areas with well-embedded norms and consensus among member states:

\footnotetext{
${ }^{2}$ We use "institution" here in two senses of the term: both formal, organizational entities as well as regimes, or recurring and stable patterns of behavior around which actor expectations converge (Keohane, 1989). For example, the "coalition of the willing" and the Proliferation Security Initiative are stable patterns even though the membership is variable. It is easier to identify formal institutions that have treaties and budgets, but the messier and more informal variety are just as essential to our analysis.
} 
the UN Children's Fund (UNICEF) and the World Health Organization (WHO), to name but two. Many issues treated by such organizations are seen as having little controversial political content — there is nothing in them that has an impact on a state's interests, and that would therefore lead to conflict. Hence, these issues can safely be turned over to experts for resolution.

In this article, we initiate a long overdue conversation on the subject of " $U N$ policy.” First, we speculate as to whether and, if yes, in what sense there is such a thing. Second, as the world organization's comparative advantage is its unique ability to formulate policies that aspire to universal application, we highlight this particular contribution to global problem-solving through a range of selected prominent contemporary issues (terrorism; sustainability; and controlling pandemics) to show how the UN has or has not filled them as part of the advance and retreat of global governance.

\section{What UN Policy?}

The universal character of the United Nations provides the kind of legitimacy that is a precious asset in formulating global public policy. Yet, who are the actors - the relevant policy-makers—in the UN system? Is “international” policy made and implemented by international organizations or by national authorities meeting and interacting in international forums? To what extent has the evident policy paralysis over Darfur been the result of a policy gap on the part of the UN as opposed to weak political will among key member states? Such an approach can lead to fragmented, incompatible policies that can become more incoherent over time. How well suited is the United Nations to determine the ends of policy, or to guide the processes by which it is made? 
The literature on international institutions provides familiar answers. To realists, international organizations like the UN are creations and tools of sovereign states, and as such, cannot be independent actors. Likewise, to traditional liberal institutionalists, the UN is an arena in which interactions among its member states take place and cooperation can be agreed. Finally, to classic principal-agent theorists, states are the principals and UN secretariats are the agents, and much of the focus is on the absolute power over international civil servants by member states that pay their salaries. As one critic explains, "P-A theory posits that the ability of the Principal to 'sanction' an Agent by changing the contract (firing or not reappointing the Agent, rewriting contractual terms to undercut the Agent's realm of authority, or cutting the Agent's budget) provides states with significant political leverage that they can use to rein in Agents who go astray” (Alter, 2008: 34).

In short, to all the above, the notion of a "UN policy" that is not reflective of the preferences and interests of the states does not seem to make any sense; but this discussion of the policy-making function of the United Nations exposes four substantial weaknesses in this rather old-fashioned view, all of which suggest rather more autonomy for agents in making policy than is commonly thought. First, recent works using a revised and more nuanced version of principal-agent theory and constructivism suggest that international organizations, including UN specialized agencies, have significant (although incomplete) autonomies vis-à-vis their principals (Barnett and Finnemore, 2004; Hawkins, Lake, Nielson, and Tierney, 2006; Nielson and Tierney, 2003; Pollack, 2003; Reinalda and Verbeek, 2004). Second, there are multiple sources of funding for activities by UN organizations so that, at a minimum, there is a deeply symbiotic relationship 
between the principals and the agents; as supposedly all the principals broadly support the objectives of less conflict and more cooperation, UN officials can seek allies and funding from a variety of sources. Third, with the retreat of the state in an age of globalization, there is more "space" available for the UN organizations because, as Janice Gross Stein (2008: 127) argues, “a principal-agent relationship looks somewhat like domestic publicprivate and public-voluntary partnerships... States no longer row, they steer.”

Finally and perhaps most importantly, in discussing UN policy, there are "three UNs” and not merely one. Beginning with Inis Claude (1956, 1996), analysts of international organization usually identify two United Nations, one comprised of member states and a second comprised of the secretariats. A third UN should be added to our analytical toolkits, comprised of actors that are closely associated with the world organization but not formally part of it (Weiss, Carayannis, and Jolly, 2009). This “outside-insider” UN includes nongovernmental organizations, academics, consultants, experts, independent commissions, and other groups of individuals. These informal networks often help to affect shifts in ideas, policies, priorities, and practices that are initially seen as undesirable or problematic by state principals and even international secretariats. As any contemporary student of the organization soon discovers, all three United Nations are essential to contemporary policy formulation by the world organization.

According to a standard reference, a policy is not only a governing principle but also "the decision to embark upon certain programs of action (or inaction) in order to achieve desired goals” (Evans and Newnham, 1998: 440). It is an intended course of action or inaction in light of a particular problem (Birkland, 2005: 17-18; Brown and 
Ganguly, 1997). This necessarily entails both agency and purposive action. State actors are policy-makers. But for states, public policy is usually distinguished from foreign policy, implying a boundary-based, domestic/external separation between the two activities. "The policy-makers and the policy system therefore stand at these junction points and seek to mediate between the various milieux" (Evans and Newnham, 1998: 179). By contrast, "the UN, through its organs such as the Security Council or the General Assembly, makes policy” (Evans and Newnham, 1998: 440), but it cannot be said to make foreign policy. Neither the policy-makers nor the policy system of the United Nations are engaged in boundary activities. By definition the world is their stage.

The civil service may shape and influence policy, but is not normally considered to be a policy-maker: that is the domain of the political heads of civil service departments, cabinet ministers individually and the legislature and political executive collectively. Likewise, the UN Secretariat and its staff members-international civil servants—may influence policy but they cannot be described as policy-makers. To the extent that in important respects the Secretary-General and other senior officials can be called independent actors in their own right (Ramcharan, 2008; Thakur, 2006), they may on some occasions be classified as peripatetic policy-makers.

Thus, UN “policymakers” are indeed the principal political organs—-the Security Council and the General Assembly — and the member states collectively. But all of these are intergovernmental forums. That is, the people making the decisions in the form of adopting resolutions that set out new governing principles, articulate goals, and authorize programs of action to achieve those goals, do so as delegates of national governments from the UN's member states. Moreover, they do so only within the governing 
framework of their national foreign policies, under strict and narrow instructions from capitals.

The UN's ability to consult widely beyond states (the First UN) plays a substantial part in its ability to formulate operational ideas: the recommendations for specific policies, institutional arrangements, and regimes that follow after identifying and diagnosing a problem and developing a norm to help codify desirable changes in behavior and approach. This is a function that is quintessentially in the job descriptions of the “Second United Nations,” staff of international secretariats often complemented by trusted consultants and expert groups in the "Third UN” (Weiss et al, 2009; Jolly, Emmerij, and Weiss, 2009). And the discussion and dissemination often occurs in public forums and global conferences (Schechter, 2005; Weiss, Carayannis, Emmerij, and Jolly, 2005: Chapters 9-11). Indeed, this is why the world organization has a comparative advantage in formulating policies for universal consideration and adaptation.

At the national level, policy can be used to refer holistically to "the entire package of actions and attitudes” (Hill, 2001: 290)—for instance, Indian or U.S. policy. Alternatively, it can also be applied to specific policies toward this or that state in foreign affairs—-for example, Indian or U.S. policy toward Israel-Palestinian relations, the International Criminal Court, nuclear proliferation-or to this or that issue in domestic affairs — for example, Indian or U.S. policy on the death penalty, intellectual property, immigration.

Policy may also be broken down sequentially into three separate phases_formulation, adoption, and implementation. And its object varies: to regulate services like transport, telecommunications, public utilities; to allocate public resources like housing, 
employment, scholarships; and to redress social inequality through social welfare programs (Morris, 2001: 703). As distinct from state actors, the responsibility for implementation of most UN policy does not rest primarily with the United Nations itself but with its member states. But even UN policy, in the form of policy resolutions and actions adopted and authorized by the Security Council and the General Assembly or summit decisions made by member states directly, may exhibit regulative, distributive, and redistributive characteristics.

Based on these considerations, resolutions adopted by the General Assemblythough not legally binding — are the equivalent of policy declarations if they articulate broad principles and goals, sometimes with programs of action to attain these goals. ${ }^{3}$ One of the clearest examples is 1972 General Assembly resolution 2922 reaffirming apartheid as a crime against humanity. The phrase became a staple of UN resolutions over many years until the liberation of South Africa and the replacement of the apartheid regime with an elected black-majority government formed by the African National Congress (ANC) with Nelson Mandela as the first president.

A second set of UN policy documents take the form of goals, plans of action, and desirable codes of conduct embedded in resolutions as well as international treaties and conventions. Good examples include the 1948 Universal Declaration of Human Rights and the Genocide Convention, the two 1966 Covenants on Civil-Political and Social, Economic and Cultural Rights, the 1982 UN Convention on the Law of the Sea (to which the United States is not a party), the 1997 Kyoto Protocol (whose implementation has

\footnotetext{
${ }^{3}$ They are similar to policy declarations in another respect as well. At the national level, unless they are in the form of a "sense of the legislature" or equivalent, acts of parliament would be binding law. UN General Assembly resolutions, however, are not legally binding, any more than policy declarations by the political executive are at the national level.
} 
fallen well short of commitments made), the 1968 Nuclear Nonproliferation Treaty (NPT, under increasing international stress in recent years: Boulden, Thakur and Weiss, 2009), and the 1996 Comprehensive Test Ban Treaty (CTBT, yet to enter into force because of non-signatures or ratifications by key states like India and the United States, yet whose provisions have been respected to date since it was signed over a decade ago—a good example of an international security policy being integrated into national security policies).

\section{International Terrorism}

The UN's primary purpose, as set out in the Charter, is the maintenance of international peace and security, but trying to develop policies within the UN system for a topic as contested as terrorism is anything but simple. An elusive definition gives one key to the problems afflicting efforts to devise common "policies" to combat and uproot terrorism.

The threat of international terrorism has been addressed internationally both within the framework of international law and specific UN resolutions and measures. In the Corfu Channel Case in 1949, the International Court of Justice (ICJ) affirmed "every State's obligation not to allow knowingly its territory to be used for acts contrary to the rights of other States” (Sahović and Bishop, 1968: 316). There are thirteen global, seven regional, and three related global treaties for combating terrorism (Boulden and Weiss, 2004), ${ }^{4}$ which could be seen as a substantial corpus of policies. Nevertheless, until the

\footnotetext{
${ }^{4}$ The thirteen international legal instruments are: (1) 1963 Convention on Offences and Certain Other Acts Committed On Board Aircraft (Aircraft Convention); (2) 1970 Convention for the Suppression of Unlawful Seizure of Aircraft (Unlawful Seizure Convention); (3) 1971 Convention for the Suppression of Unlawful Acts against the Safety of Civil Aviation (Civil Aviation Convention); (4) 1973 Convention on the Prevention and Punishment of Crimes Against Internationally Protected Persons (Diplomatic Agents Convention); (5) 1979 International Convention against the Taking of Hostages (Hostages Convention); (6)
} 
1970s, terrorism in UN circles was viewed largely as a local phenomenon. As the frequency, violence, and reach of terrorist incidents began to expand, the General Assembly seemed to be as interested in understanding and rationalizing terrorism as in suppressing it, while the Security Council was more exercised by the counter-terrorism tactics of Israel and the United States than by the acts of terrorism themselves (Luck, 2004: 98). This reflected the changed composition of the overall UN membership in the aftermath of the decolonization of Asia and Africa in particular from European rule, the reality of many armed national liberation movements that had resorted to acts that many Western governments condemned as terrorism, ${ }^{5}$ and the vote mobilizing capacity of the Arab and Islamic countries in the General Assembly that culminated most shamefully in the notorious resolution equating Zionism with racism. Furthermore, many of the traditional support constituencies of the UN are instinctively suspicious of actions to counter terrorism. Human rights groups want their pet cause factored in; humanitarian actors and arms control activists are worried about rollbacks to international humanitarian law and disarmament; and many developmentalists want to limit the diversion of resources from development and the "root causes” of terrorism like poverty and inequality.

The day after 9/11, both the Security Council and the General Assembly adopted

1980 Convention on the Physical Protection of Nuclear Material (Nuclear Materials Convention); (7) 1988 Protocol for the Suppression of Unlawful Acts of Violence at Airports Serving International Civil Aviation, supplementary to the Convention for the Suppression of Unlawful Acts against the Safety of Civil Aviation (Airport Protocol) ; (8) 1988 Convention for the Suppression of Unlawful Acts against the Safety of Maritime Navigation (Maritime Convention); (9) 1988 Protocol for the Suppression of Unlawful Acts Against the Safety of Fixed Platforms Located on the Continental Shelf (Fixed Platform Protocol) ; (10) 1991 Convention on the Marking of Plastic Explosives for the Purpose of Detection (Plastic Explosives Convention) ; (11) 1997 International Convention for the Suppression of Terrorist Bombings (Terrorist Bombing Convention) ; (12) 1999 International Convention for the Suppression of the Financing of Terrorism (Terrorist Financing Convention); and (13) 2005 International Convention for the Suppression of Acts of Nuclear Terrorism (Nuclear Terrorism Convention).

${ }^{5}$ It was only in 2008 that the African National Congress, for example, was delisted by the U.S. government as a terrorist organization. 
resolutions strongly condemning the acts of terrorism and urging all states to cooperate to bring the perpetrators, organizers, and sponsors of 9/11 to justice. Security Council resolution 1368 was the first to incorporate acts against terrorism into the right of selfdefense. In doing so, the council effectively provided a blank check to Washington and sidelined itself from oversight of the measures taken in response. Two weeks later, Security Council resolution 1373, adopted under Chapter VII, imposed significant requirements on member states within their domestic jurisdictions and expanded the council's oversight role in relation to them. "This posed a remarkable dichotomy. The Security Council chooses to exercise no control or oversight on the use of military force in response to terrorism but is vigilant and arguably intrusive when it comes to dealing with terrorism through national mechanisms and controls” (Boulden and Weiss, 2004: 11). Moreover, because neither "self-defense" nor "terrorism" is defined or selfexplanatory, the result "compounds the [unlimited] expansiveness of the mandate" (Boulden and Weiss, 2004: 11-12).

Security Council resolution 1540 of April 2004 broke new conceptual ground in formulating a policy directing sovereign states to enact nonproliferation legislation. Affirming the proliferation of weapons of mass destruction (WMDs) as a threat to international peace and security—which kicks in the binding-on-all collective enforcement Chapter VII of the UN Charter-and expressing concern over the threat of WMDs terrorism and of illicit trafficking in such material, weapons, and delivery systems, this resolution obliged states to enact and enforce laws to prohibit nonstate actors to develop, acquire, transfer or use WMDs; to take and enforce effective domestic control, physical protection, accounting and border control measures to prevent 
proliferation; and to set up a committee of the whole to oversee implementation of the resolution.

The unprecedented intrusion into national law-making authority can be read as the toughened new determination to take effective action. But it was not without controversy: "the UN Charter makes no provision for the Council to engage in such global lawmaking, and the imposition of such obligations runs counter to the principle that international law is based on the consent of states” (Burroughs, 2007: 32). A former member of the UN/OAU Expert Group on the Denuclearization of Africa noted that "by arrogating to itself wider powers of legislation,” the Security Council departed from its Charter-based mandate, and that excessive recourse to Chapter VII could signal a preference for coercion over cooperation (Mohammad, 2004). Framing the resolution within the global war against terrorism was meant to silence dissenting voices. And the council's effort to seek global adherence to its resolutions was undermined by its unrepresentative composition and the veto power of the five permanent members (P-5) (Mohammad, 2004). Many NGOs too criticized the resolution's silence on the role of disarmament in promoting nonproliferation, as well as the Security Council's effort to transform itself into a world legislature (Wurst, 2004).

On 13 April 2005, after seven years of negotiations, the General Assembly unanimously adopted the "International Convention for the Suppression of Acts of Nuclear Terrorism.” The thirteenth UN convention against terrorism, which was opened for signature on 14 September 2005 and entered into force on 7 July 2007, makes it a crime to possess or demand radioactive material or device with the aim of causing death or serious injury or substantial damage to property. It calls on states to adopt national 
laws to make these acts criminal and to provide for appropriate penalties for those convicted of such acts.

The criticisms and the extent of their validity notwithstanding, these three Security Council resolutions along with the International Convention for Suppression of Terrorist Financing have led to an impressive number of practical steps to restrict potential terrorists by denying them the financial means for their nefarious activities, freezing their assets, restricting their freedom of movement across borders, and denying them the weapons to commit terrorist acts. Moreover, the thirteen global treaties define, proscribe, and punish such individual categories of terrorism as hijacking, piracy, ${ }^{6}$ hostage taking, bombing civilians, procuring nuclear materials, and financing terrorist activities. While they do not address the totality of terrorist acts within one comprehensive normative or institutional framework, they do constitute a significant body of policies to which states can aspire.

In short, these fledgling policy steps have had consequences even if there is no operational capacity to ensure implementation. Moreover, currently member states are negotiating a fourteenth international treaty, a draft comprehensive convention on international terrorism that would complement the existing framework of international anti-terrorism instruments and build on the key guiding principles already present in the existing thirteen anti-terrorist conventions: the importance of criminalization of terrorist offences, making them punishable by law and calling for prosecution or extradition of the perpetrators; the need to eliminate legislation which establishes exceptions to such criminalization on political, philosophical, ideological, racial, ethnic, religious or similar

\footnotetext{
${ }^{6}$ Although hijacking is covered by the first three of the thirteen conventions listed above, and maritime navigation is covered by the eighth convention, piracy as such is not a specific crime addressed by any of the existing international legal instruments.
} 
grounds; a strong call for member states to take action to prevent terrorist acts; and emphasis on the need for member states to cooperate, exchange information and provide each other with the greatest measure of assistance in connection with the prevention, investigation and prosecution of terrorist acts.

In his report, Annan (2005: Para. 88) outlined five policy pillars of a counterterrorism strategy: dissuasion of people from resorting to or supporting terrorism; denial of access to funds and materials to terrorists; deterrence of states from sponsoring terrorism; capacity development so states can defeat terrorism; and defense of human rights. The 2005 World Summit endorsed the Secretary-General's strategy (United Nations, World Summit Outcome, 2005: Paras. 81-83), and he subsequently (in May 2006) presented his proposal to the General Assembly, in which he further refined his previous year's thinking (Annan, 2006).

Based on consultations shaped by this report, on 8 September 2006, the General Assembly unanimously adopted, in resolution 288, the Global Counter-Terrorism Strategy as the common platform to bring together the efforts of the various UN entities into a coherent framework. For the first time, all 192 member states agreed on a common approach—or policy—to fight terrorism.

The United Nations has become the forum of choice for regime negotiation and norm promotion in countering international terrorism, one of the most contested contemporary policy issues. Indeed, the establishment of a regime through an interlocking collection of treaties and conventions is one of the more powerful achievements of the UN system over the past decade. To be sure, it lacks enforcement capacity, but it can promulgate and promote the normative and legal framework of a 
counter-terrorism regime. It can also be the coordinating forum for counter-terrorism efforts by states, regional organizations, and technical agencies like the International Atomic Energy Agency (IAEA). With respect to biological and chemical weapons, the UN could be the central coordinator and clearing house for information, aligning the work of national and functional agencies; and a clearing house for the global stockpiling and distribution of drugs and vaccines in a global crisis. Just as importantly, the world organization with its multitude of offices, funds, programs, and specialized agencies, is also the forum of choice for attacking the "conditions conducive to the spread of terrorism including prolonged unresolved conflicts, dehumanization of victims of terrorism in all its forms and manifestations, lack of the rule of law and violations of human rights, ethnic, national and religious discrimination, political exclusion, socioeconomic marginalization and lack of good governance” (United Nations, UN Action to Counter Terrorism, 2008).

\section{From Sustainable Development to Climate Change}

One of the biggest contemporary global policy gaps concerns the redistribution of the benefits of growth. The litany of policies that emerged as part of the "dialogue of the deaf" in the mid-1970s would provide an intriguing illustration of policy gaps that remain gigantic to this day. Rather than going down this well-trodden path of the collapse of the new international economic order (NIEO), however, it would provide more insights about moving toward policy relevance to explore the ever-changing dynamics of policy gaps on the protection of the human environment by returning to the "Earth Summit" of June 
1992 in Rio de Janeiro, known formally as the UN Conference on Environment and Development (UNCED).

After several years of in-depth preparations, once again (following the 1972 UN Conference on the Human Environment in Stockholm) Maurice Strong headed the UN's team as secretary-general of the conference, which broke existing records in terms of both its size and the scope of its concerns (DeSombre, 2006). The participation and contributions by NGOs were far more extensive than twenty years earlier in Stockholm, where their political participation in a parallel "forum” was a first in international conferencing techniques. In addition, the end of the Cold War facilitated the burgeoning of civil society throughout the socialist bloc and many parts of the developing world. NGOs mobilized public opinion around the world and were able to shape to a large extent Agenda 21 (the final product of Rio). The Rio Declaration in many ways consummated the key ideas put on the table by the meeting of experts at Founex in 1971. In short, steps were taken to fill the policy gaps by moving toward defining the content of a global partnership between developing and more industrialized countries based on mutual needs and common interests in order to make possible a healthier future for the planet.

Of course, the range of environmental issues had evolved in the twenty years between Stockholm and Rio. Global problems were agreed to include the ozone layer and global warming, tropical deforestation, the biosphere, and problems of permanent sovereignty of resources — all this in the framework of sustainable development. However, the North-South divide had not changed significantly: northern countries sought legal obligations to protect the environment from harmful development policies, while southern governments continued to see this as a threat to their national sovereignty 
and a menacing limitation on their economic growth possibilities (Schechter, 2005: 119).

Agenda 21 “set international and national objectives and provided programmatic suggestions on how to fulfill those objectives” (Schechter, 2005: 121). With more than 1,000 specific policy recommendations in areas as widely diverse as desertification and poverty eradication, Michael Schechter (2005: 157) goes on to explain that although Agenda 21 led to the more systematic consideration of sustainable development within the UN system, it has not been used as such by national governments; in fact, it has "failed to serve as a useful guide to action."

The most recent consolidation of attempts to frame and pursue sustainable development policies are found in the 2000 Millennium Development Goals (MDGs) which ultimately are policy goals. In particular, MDG 7 and MDG 8 are "Ensure environmental sustainability” and “Develop a global partnership for development,” respectively. The first target in MDG 7 explicitly addresses the failure of Agenda 21: "Integrate the principles of sustainable development into country policies and programs and reverse the loss of environmental resources” (Sachs, 2005: 212). The MDGs have target dates of 2015, indicating that the goals are attainable if political will can be mustered. The review of these policy goals at the 2005 World Summit indicated, however, that five years had passed without substantial progress.

But major progress has been recorded and rare international success achieved with an earlier environmental goal and policy instrument. If chlorofluorocarbons (CFCs) contribute to depleting the ozone layer which in turn causes various harms to flora and fauna as well as to human beings, then the use of CFCs has to be curtailed and eliminated. That was the purpose behind and the goal of the Montreal Protocol in which 
signatories undertook to phase out the production and use of ozone-depleting compounds, such as CFCs.

The Montreal Protocol on Substances that Deplete the Ozone Layer, signed in 1987 and in force since 1 January 1989, was a ground-breaking international agreement that, building on its “parent” instrument the 1985 Vienna Convention for the Protection of the Ozone Layer, first slowed and then reversed the thinning of the ozone layer. In recognition of the principle of common but differentiated responsibility of industrialized and developing countries, all countries were required under the Montreal Protocol to cut back on ozone-depleting substances, but developing countries were given a ten-year grace period and financial incentives. It has virtually universal support—its 191 signatories (the non-signatories are Andorra, East Timor, Iraq, San Marino, and the Vatican $^{7}$ ) have increased from 24 at inception and have phased out more than 95 percent of ozone-depleting substances, and the earth's protective ozone layer is estimated to return to pre-1980 levels by 2075 (Ozone Secretariat, 2008). As the most significant legally binding international environmental agreement that engaged both industrialized and developing countries since the 1973/1978 International Convention for the Prevention of Pollution From Ships (MARPOL) and the 1975 Convention on Wetlands of International Importance (RAMSAR), the Montreal Protocol should have ushered in an era of global environmental responsibility. Unfortunately, the familiar story of continuing climate change tells us “it ain’t so.” Nevertheless, the success of the Montreal Protocol in its own terms is worth noting because it provides clues to the elements of a workable “policy” for the future.

\footnotetext{
${ }^{7}$ The Holy See (Vatican), not a UN member state, is an actor in world affairs as an independent legal entity and in that capacity has formal observer status at the United Nations.
} 
In 1990 the General Assembly decided to initiate negotiations on a framework convention on climate change, to be completed prior to UNCED in Rio de Janeiro in June 1992. The UN Framework Convention on Climate Change (UNFCCC) was adopted on in May 1992, opened for signature in June 1992 at UNCED, and entered into force in March 1994.

In terms of moving the "policy" agenda forward, in 1988, two UN organizations — the World Meteorological Organization (WMO) and the United Nations Environment Programme (UNEP) — created the Intergovernmental Panel on Climate Change (IPCC), an independent scientific body tasked to evaluate the risk of climate change caused by human activity. In the Geneva Ministerial Declaration at the Second Conference of the Parties to the Climate Change Convention (COP-2) in 1996, members accepted the conclusions by the IPCC—-which have become considerably less contested in the last decade - that human behavior influences global climate; that the projected changes in climate will result in significant, often adverse, and in some cases potentially irreversible, impacts on many ecological systems and socio-economic sectors, including food supply and water resources, and on human health; and that significant reductions in net greenhouse gas (GHG) emissions are technically possible and economically feasible by utilizing an array of technology policy measures that accelerate technology development, diffusion, and transfer. The Berlin Mandate process led to the adoption of the Kyoto Protocol at COP-3 (1997).

The case for environmental protection no longer rests on a lack of knowledge about a threat or the lack of empirical data. It now rests on the policy gap between the efficacy of two opposing ideologies, neo-liberal economics and sustainable development. 
The Kyoto Protocol was negotiated in 1997 and went into effect in February 2005 with Russia’s ratification. It sets targets for industrialized nations (also known as the "Annex 1" countries, from those that figure in a list in the first annex to the protocol) to cut their GHG emissions, but not for developing countries_-including such behemoth and fast growing economies as China and India that rival the United States for the dubious distinction as the world champion polluter.

The goal of the Kyoto Protocol and the UNFCC is to stabilize GHG concentrations in the atmosphere at a level that will stop and then reverse harmful global warming. Under the UNFCC, thirty-six industrialized countries and transition economies have legally binding GHG emission limitation and reduction commitments, while developing countries have non-binding obligations to limit emissions.

There were two reasons why the IPCC's Fourth Assessment Report was the most forceful and specific of all. First, the panel was greatly buoyed by the announcement of the Nobel Peace Prize—-shared with Al Gore for his An Inconvenient Truth—a month before its meeting in Valencia. Second, the IPCC was conscious that its document would help to define policy at the UN conference in Bali within a month. The hope was to generate a policy response in Bali “quick enough and big enough,” in the words of Princeton University’s Michael Oppenheimer, one of the IPCC’s scientists (Quoted in Rosenthal, 2007). The policy urgency came from the startling conclusion that by 2007 the world was already at or beyond the pessimistic end of the IPCC's trajectory of emissions and global warming. Indeed, some scientists feared that the IPCC report had under-stated the scale and rapidity of global warming and its impacts. The panel deliberately laid out the consequences of different degrees of climate change, the different options, and the 
consequences and costs of deferring action.

The December 2007 Bali conference began the painstaking negotiations on a successor regime for the Kyoto Protocol when it expires in 2012. It was the setting for the most recent illustration of the unwillingness of states to face the dramatic consequences of failing to formulate a consensual policy for global warming. Secretary-General Ban Ki-moon pleaded with delegates to "deliver to the people of the world a successful outcome” (Quoted in Jowit, Davies, and Adam, 2007). The conference’s dramatic eleventh hour included tears from the head of the UN Climate Change Secretariat, and Papua New Guinea’s open challenge to the United States: “If you're not willing to lead, get out of the way” (Quoted in Jowit et al, 2007).

After the deadline for an agreement had been reached, 187 states present (including China and the United States) unexpectedly resumed talks on the global effort to rescue the planet from climate change, which culminated in the so-called Bali roadmap. Deep concessions were made so that the United States would sign on, yet the United States still had serious concerns about the inadequacy of responsibilities assigned to developing countries, while Russia, Canada, and Japan also objected to some of the agreement's key aspects. Meanwhile the G-77 and some NGOs were disappointed at the lackluster final text. Indeed, the ambassador of Grenada described the outcome as "so watered-down" that "there was no need for 12,000 people to gather...in Bali. We could have done that by email” (Quoted in Jowit et al, 2007).

The "policy gaps” to reach this norm could be filled through the twin-track of stringent mitigation and strengthened international cooperation on adaptation. On mitigation, the industrial countries are supposed to own up to their historical 
responsibility and take the lead in cutting their 1990 GHG levels by 30 percent by 2020 and 80 percent by 2050. This can be done through a mix of carbon taxation; more stringent cap-and-trade programs; energy regulatory standards on vehicle emissions, buildings, electrical appliances; and greater recourse to renewable energies and carbon capture and storage.

Developing countries have lesser responsibility for having created the climate change problem and lesser capacity for both mitigation and adaptation; although such new economic giants as India, Brazil, and China clearly no longer have the same claim as smaller, poorer developing countries. They therefore need more transition time, financing for low-carbon technology transfer, and assistance with adaptation. Their target should be set at cutting emissions by 20 percent of 1990 levels by 2050, starting from 2020 and supported by international transfers of finance and low-carbon technology. UNDP’s Human Development Report, 2007/2008 recommends the creation of a climate change mitigation facility to provide $\$ 25-50$ billion annually toward incremental low-carbon energy investments in developing countries.

Even with a policy in place of stringent mitigation, warming will continue at least until 2050. Adaptation is necessary to cope with the implications of this and as insurance against the threat of insufficiently stringent mitigation. Here again, differential capacity between the rich and poor countries carries the risk of, in the words of Desmond Tutu, “adaptation apartheid” (Quoted in UNDP, Human Development Report, 2007: 13). The spending to date on multilateral mechanisms on adaptation total a mere \$26 million, with high transaction costs associated with such low levels of financing. Additional annual financing for adaptation—-for climate proofing infrastructure and building resilience, for 
example—will require \$86 billion by 2015 .

The basic policy framework for making decisions on the appropriate level of global mitigation is one of risk management guided by the principles of actual and avoided climate change damages, co-benefits, sustainability, equity, and attitudes to risk. In sum, "Choices about the scale and timing of GHG mitigation involve balancing the economic costs of more rapid emission reductions now against the corresponding medium-term and long-term climate risks of delay” (Intergovernmental Panel on Climate Change, 2007: 18-19). Public policy instruments (regulations and standards, taxes and charges, financial incentives, integrating climate policies in broader development policies) are important, based on four criteria: environmental effectiveness, cost effectiveness, distributional effects (including equity), and institutional feasibility. If these policies are to succeed, governments have to be onboard. Their support is crucial through financial contributions, tax credits, standard setting, and market creation. In 2008, the rest of the world effectively decided to mark time until the U.S. presidential elections were over and the winning candidate known. Serious negotiations about policies for a post-Kyoto regime are likely to resume, therefore, only in 2009.

\section{Controlling Pandemics}

The international community can readily call on the experience of a successful campaign to eradicate a major killer disease when the norm of eradication is accepted, the political will is mustered, and the necessary financial, organization resources are fully mobilized. The elimination of smallpox is perhaps the most spectacular illustration of why having a normative consensus, solid knowledge, and sensible policy is essential. For more than 
3,000 years, smallpox was a scourge of humankind, feared for its high fatality—often 10 percent of all deaths each year-and for the pockmarks which disfigured those who survived. In the early 1950s—a century and a half after the introduction of vaccinationan estimated 50 million cases of smallpox occurred in the world each year, a figure which fell to around 10-15 million by 1967 because of vaccination (WHO, Fact Sheet/Smallpox, 2008), of whom some 2 million people succumbed to the disease in that year (Fenner et al., 1998; Black, 1986). Lest we forget, the WHO is a specialized agency of the UN system.

In 1953, the WHO’s first director-general, Brock Chisholm, made an unsuccessful attempt to persuade the World Health Assembly—-the WHO's governing body—-to undertake a global program for smallpox eradication. Five years later, a Soviet delegate persuaded the WHO to accept responsibility for a global program—but only minimal funds were provided. The organization itself was preoccupied with a major and eventually unsuccessful effort to eradicate malaria, and many were skeptical about the feasibility of smallpox eradication, especially in Africa.

In 1966, the World Health Assembly agreed on an Intensified Smallpox Eradication Program (ISEP)—-though still with doubts about its success. At that time, the entire staff numbered just over 3,300 persons, and only about 150 professionals were available to oversee smallpox programs in more than fifty countries.

Once started, the program advanced rapidly. A strategic plan concentrated on mass vaccination campaigns, using freeze dried vaccines of quality assessed by special teams. A surveillance system was set up to detect and investigate cases and contain outbreaks. Three principles were critically important. First, all countries would need to 
participate, with some form of regional and global coordination. Second, programs would need to be flexible and adapted to the specifics of each country. Finally, ongoing research, in the field and the laboratory, would be needed to evaluate progress and solve problems as they arose.

By the early 1970s, smallpox was on the retreat. A surveillance containment strategy was developed, sending flying squad teams wherever a possible case was discovered. The squads would make a diagnosis, identify and vaccinate all contacts, and swiftly contain the spread of infection. By 1975, the number of countries where the disease could still be found had fallen from 30 to 3-India, Bangladesh, and Ethiopia. By the end of the year, the last case of variola major, the most serious form of the disease, was reported in Bangladesh.

Attention then turned to Ethiopia, where the last case was reported in August 1976 — but not before nomads had carried the disease across the border into Somalia, where an epidemic occurred in mid-1977. In October, the last case, of variola minor, was finally reported in Somalia. Three years later, the WHO declared victory. The total cost of the 11-year effort had been around \$300 million, one third of which came from international sources and two thirds from the countries affected. The total cost was the equivalent at the time of three fighter-bombers. Saved lives is an impressive variable for some, and even hard-headed accountants have to be impressed by the purely economic benefits of the implementation of the policy. Because of eradication, the world now saves at least $\$ 2$ billion each year by avoiding the purchase of smallpox vaccine, administration (including applying international health regulations), and related costs. This certainly is one clear economic way to measure the importance of redefining sovereignty to include 
fighting diseases farther afield with as much vigor as diseases closer to home. Most of the savings have been in the budgets of industrialized countries, which have been able to avoid the up-front investment costs of vaccination and smallpox health regulations.

The eradication of polio, inspired in part by the successful experience with smallpox, is underway. The vaccines invented by Jonas Salk (1955) and Albert Sabin (1962) made it possible — with adequate resources and international cooperation that ignored national boundaries_- to come close to extinguishing this disease. Some 150 countries have reported no case for three or more years. Efforts underway by WHO and UNICEF may soon conquer this disease.

To date, the HIV/AIDS pandemic_-and the near misses with SARS and avian flu - have reflected a different approach from that of smallpox and polio. Of course, the clarity of understanding regarding the virology and epidemiology of smallpox was a precondition for its eradication. Nonetheless, the early embrace of cooperation and transnational interests and a normative agenda rather than going it alone on a national basis also was essential. The HIV/AIDS story is one of waking up after the disaster has struck and of proceeding with minimal international cooperation.

The response by Western governments was initially sluggish but then reasonably effective once the urgency and magnitude of the crisis was fully grasped. The response by African governments was and often remained one of denial, evasion, and resort to conspiracy theories. The UN system's response demonstrates a disconnect between the swelling international bureaucracy and results obtained in the field. Yet it is the UN system that aggressively promotes the ethic of a comprehensive response to get ahead of the epidemic: HIV prevention efforts should be intensified and scaled up while 
simultaneously expanding access to treatment and care. According to the Joint United Nations Programme on HIV/AIDS (UNAIDS), scaling-up available prevention strategies in 125 low- and middle-income countries would avert 28 million new infections in 20052015 — more than half the projected new infections on present trends and interventions and save \$24 billion in treatment costs (UNAIDS, Global Facts and Figures, 2006).

The initial U.S. policy response, at the time of the Reagan administration in the 1980s, was one of confusion, uncertainty, and buck-passing (Shilts, 2007). But not for long as both the government and the activist gay community publicized the threat of the frightening new disease. The government funded research into causes, treatment, and preventive strategies while the gay community encouraged safe sex practices as the primary method of reducing infection rates. The net result was that HIV/AIDS did not spread significantly into the heterosexual population and has been kept mostly under control through expensive yet widely available antiretroviral drugs. The U.S. pattern has been more or less replicated in all the industrialized Western countries.

Such is not the case in Africa, which has been the main theater where this particular tragedy has played out. Because of the inadequacies already detailed above, the disease has cross-infected the heterosexual population in general and is still spreading more widely. In 2007, 22.5 million sub-Saharan Africans were believed to be HIVpositive and another 1.7 million were being infected each year as well (UNAIDS and WHO, AIDS Epidemic Update, 2007).

The international AIDS industry often privileges the goal of capturing more funding and meeting donor priorities than effective problem solving in the countries and populations in need and at risk. For example, unlike the worldwide industry behind the 
distribution of condoms as an AIDS prevention policy, there is no multimillion industry and bureaucracy to profit from and so no support for a policy of single partner sexual fidelity and abstinence-a policy of “zero grazing” that was remarkably successful in Uganda.

The World Bank's HIV/AIDS policy is set out in a handbook that embraces “managing for results” (governance by slogan is an incurable ailment of international organizations) (Global HIV/AIDS Monitoring and Evaluation Team, 2007). This consists of a continuous six-stage virtuous cycle presented in a fashionable flow-chart: formulate or revise the HIV strategy $\rightarrow$ analyze the evidence with respect to outcomes and indicators $\leftrightarrow$ select the critical interventions, cost them and identify the resources for funding them $\rightarrow$ monitor the results $\rightarrow$ evaluate the changes in the epidemic $\rightarrow$ feed the evidence into the next strategy. To make progress, there is a need to scale up and sustain HIV prevention, treatment, and follow-up care. To make the programs more effective, there is a need to integrate HIV into national development plans and enter into partnerships at the country and international level.

At present, the UNAIDS offers a six-point policy template for dealing with HIV (GreenFacts, 2008): ${ }^{8}$

1. Strengthen prevention services and education targeted especially at high-risk cohorts like young people, HIV-infected pregnant women, drug users, prostitutes, homosexuals, prisoners;

2. Improve access to treatment and care;

3. Expand and strengthen human resources and systems;

\footnotetext{
${ }^{8}$ The Scientific Facts on AIDS is summarized from the UNAIDS 2006 Report on the Global AIDS Epidemic. The various recommendations and prescriptions from UNAIDS publications are available on the website at: http://www.unaids.org/en/KnowledgeCentre/Resources/Publications/.
} 
4. Make prevention and treatment products (condoms, ARV drugs) more widely available and affordable through appropriate fiscal, monetary, and regulatory instruments;

5. Invest in research and development (R\&D); and

6. Focus on the social impacts of AIDS to counter ignorance, stigma, and discrimination.

Again, the UN system's efforts to formulate policy demonstrate the comparative advantage of a universal system dealing with the global governance of pandemics. As Mark Zacher and Tania Keefe (2008) have indicated, we are “united by contagion.”

\section{Conclusion}

That the stage of international relations is occupied by several actors has become so commonplace an observation as to be trite. Actors have policies. International organizations (IGOs) are one type of the numerous actors playing diverse roles in world affairs, and the United Nations is a key IGO actor. The question of whether the world organization can be said to have any policies is theoretically intriguing and yet, surprisingly, so far largely unaddressed in the literature. Part of the exploration must include the question of the conceptual and theoretical boundaries between norms, laws and policies, and how the three are inter-related.

As noted earlier, we hope to begin a conversation among scholars and practitioners on the subject. To that end, this article suggests that in the three key issue areas discussed above, a compendium of UN policies would include:

- Dissuasion of people from resorting to or supporting terrorism;

- Denial of access to funds and materials to terrorists; 
- Deterrence of states from sponsoring terrorism;

- Capacity development so states can defeat terrorism;

- Defense of human rights even when hunting down terrorists;

- Promotion of economic growth to satisfy the aspirations of the present generation without compromising the needs of future generations or irreversibly damaging the environment and the ecosystem;

- Promotion of economic growth in the poorest countries through technical and financial assistance and concessionary terms of trade in various iterations of partnerships of development;

- Protection of the ozone layer through the Montreal Protocol;

- Deceleration, halt and reversal of global warming through the Kyoto Protocol, the UNFCCC and successor regimes and agreements;

- Eradication of smallpox and polio; and

- Control of the HIV/AIDS pandemic through the three-track strategy of prevention, treatment and education.

For all of these issue areas, the universal UN system has made solid use of its unique legitimacy and helped initiate steps toward the formulation of coherent global policies. While the policy glass is more than half full, when key member states turn recalcitrant, clearly the implementation one is close to empty. That remains the fundamental reality of global governance in a state-centric world. 


\section{References}

ALTER, KAREN. (2008) “Agents or Trustees? International Courts in their Political Context.” European Journal of International Relations 14(1): 33-63.

ANNAN, KOFI. (2004) The Rule of Law and Transitional Justice in Conflict and Postconflict Societies. Report of the Secretary-General. New York: United Nations.

ANNAN, KOFI. (2005) In Larger Freedom: Towards Development, Security and Human Rights for All. Report of the Secretary-General. New York: United Nations.

ANNAN, KOFI. (2006). Uniting Against Terrorism: Recommendations for a Global Counter-terrorism Strategy. Report of the Secretary-General. New York: United Nations.

BARNETT, MICHAEL, AND MARTHA FINNEMORE. (2004). Rules for the World: International Organizations in Global Politics. Ithaca: Cornell University Press.

BARNETT, MICHAEL, AND THOMAS G. WEISS. Eds. (2008) Humanitarianism in Question: Politics, Power, Ethics. Ithaca, N.Y.: Cornell University Press.

BIRKLAND, THOMAS. (2005) An Introduction to the Policy Process: Theories, Concepts, and Models of Public Policy Making. New York: ME Sharp.

BLACK, MAGGIE. (1986). The Children and the Nations: The Story of UNICEF. New York: UNICEF.

BOULDEN, JANE, RAMESH THAKUR AND THOMAS G. WEISS, Eds. (2009) The United Nations and Nuclear Orders. Tokyo: United Nations University Press.

BOULDEN, JANE, AND THOMAS G. WEISS, Eds. (2004) Terrorism and the UN: Before and After September 11. UN Intellectual History Project. Bloomington: Indiana University Press.

BOULDEN, JANE, AND THOMAS G. WEISS. (2004) "Whither Terrorism and the United Nations?” in Terrorism and the UN: Before and After September 11, edited by Jane Boulden and Thomas G. Weiss. Bloomington: Indiana University Press.

BROWN, MICHAEL, AND SUMIT GANGULY. (1997) “Introduction.” In Government Policies and Ethnic Relations in Asia and the Pacific, edited by Michael Brown and Sumit Ganguly. Cambridge: MIT Press.

BURROUGHS, JOHN. (2007) “The WMD Commission One Year On: Impact and Assessment,” Disarmament Diplomacy 85(Summer).

CLAUDE, JR., INIS L. (1956) Swords Into Plowshares: The Problems and Prospects of International Organization. New York: Random House. 
CLAUDE, JR., INIS L. (1996) "Peace and Security: Prospective Roles for the Two United Nations,” Global Governance 2(3): 289-298.

DESOMBRE, ELIZABETH. (2006) Global Environmental Institutions. London: Routledge.

EVANS, GRAHAM, AND JEFFREY NEWNHAM. (1998) The Penguin Dictionary of International Relations. London: Penguin Books.

FENNER, FRANK, ET AL. (1988) Smallpox and its Eradication. History of International Public Health No. 6. Geneva: WHO.

GLOBAL HIV/AIDS MONITORING AND EVALUATION TEAM. (September 2007) The Global HIV/AIDS Program: A Handbook. Washington DC: World Bank.

GREENFACTS. (2008) Scientific Facts on AIDS: Status and Challenges of the

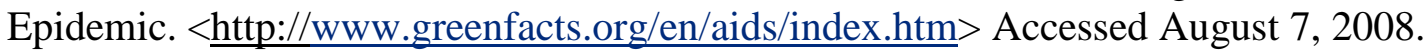

HAWKINS, DARREN, DAVID LAKE, DANIEL NIELSON, AND MICHAEL TIERNEY, Eds. (2006) Delegation and Agency in International Organizations. New York: Cambridge University Press.

HILL, CHRISTOPHER. (2001) “Foreign Policy.” In The Oxford Companion to the Politics of the World, $2^{\text {nd }}$ ed., edited by Joel Krieger. Oxford: Oxford University Press.

HUBERT, DON. (2000) The Landmine Ban: A Case Study in Humanitarian Advocacy. Occasional Paper \#42. Providence, RI: The Watson Institute for International Studies, Brown University.

INTERGOVERNMENTAL PANEL ON CLIMATE CHANGE (IPCC). (2007) Summary for Policymakers: Contribution of Working Group III to the Fourth Assessment Report of the IPCC. Geneva: IPCC.

JOINT UNITED NATIONS PROGRAMME ON HIV/AIDS (UNAIDS). (2007) Global Facts and Figures 2006. <http://data.unaids.org/pub/GlobalReport/2006/200605FS_globalfactsfigures_en.pdf> Accessed November 18, 2007.

JOINT UNITED NATIONS PROGRAMME ON HIV/AIDS (UNAIDS) AND WORLD HEALTH ORGANIZATION (WHO). (2007) AIDS Epidemic Update: December 200. Geneva: UNAIDS and WHO.

JOLLY, RICHARD, LOUIS EMMERIJ, AND THOMAS G. WEISS. (2009) UN Ideas Changing History. UN Intellectual History Project. Bloomington: Indiana University Press, forthcoming. 
JOWIT, JULIETTE, CAROLINE DAVIES, AND DAVID ADAM. (December 16, 2007) "Late-night Drama Pushes US into Climate Deal," The Observer.

KEOHANE, ROBERT. (1989) International Institutions and State Power: Essays in International Relations Theory. Boulder: Westview Press.

LUCK, EDWARD C. "Another Reluctant Belligerent: The United Nations and the War on Terrorism," In The United Nations and Global Security, edited by Richard M. Price and Mark W. Zacher. New York: Palgrave Macmillan.

MOHAMMAD, ABDALNAHMOOD ABDALHALEEM. (May 28, 2004) "Security Council and Non-proliferation.” The Hindu (Chennai).

MORRIS, LORENZO. (2001) "Public Policy.” In The Oxford Companion to the Politics of the World, $2^{\text {nd }}$ ed., edited by Joel Krieger. Oxford: Oxford University Press.

NIELSON, DANIEL, AND MICHAEL TIERNEY. (2003) "Delegation to International Organizations: Agency Theory and World Bank Environmental Reform.” International Organization 57: 241-76.

OZONE SECRETARIAT (2008) Official Website. <http://ozone.unep.org> Accessed August 7, 2008.

POLLACK, MARK. (2003) The Engines of European Integration. New York: Oxford University Press.

PRICE, RICHARD. (1998) "Reversing the Gun Sights: Transnational Civil Society Targets Land Mines.” International Organization 52 (3): 613-644.

RAMCHARAN, BERTRAND G. (2008) The UN and Preventive Diplomacy. UN Intellectual History Project. Bloomington: Indiana University Press.

REINALDA, BOB, AND BERTJAN VERBEEK, Eds. (2004) Decision Making Within International Organizations. London: Routledge.

ROZENTHAL, ELIZABETH. (November 17, 2007) “U.N. Report Describes Risks of Inaction on Climate Change.” New York Times.

RUGGIE, JOHN GERARD. (2001) “global_governance.net: The Global Compact as Learning Network.” Global Governance 7 (4): 371-378.

RUGGIE, JOHN GERARD. (2007) “Business and Human Rights: The Evolving International Agenda.” American Journal of International Law 101 (October): 819-840.

SACHS, JEFFREY D. (2005) The End of Poverty: Economic Possibilities for Our Time. New York: Penguin Press. 
SAHOVIC, MILAN, AND WILLIAM W. BISHOP. (1968) "The Authority of the State: Its Range with Respect to Persons and Places.” In Manual of Public International Law, edited by Max Sørensen. London: Macmillan.

SCHECHTER, MICHAEL G. (2005) United Nations Global Conferences. London: Routledge.

SHILTS, RANDY. (2007) And the Band Played On: Politics, People and the AIDS Epidemic. $2^{\text {nd }}$ ed. New York: St. Martin's Griffin Press.

SIMONS, MARLISE. (October 22, 2004) "Iraqis Not Ready for Trials; U.N. to Withhold Training.” New York Times.

STEIN, JANICE GROSS. (2008). "Humanitarian Organizations: Accountable--Why, to Whom, for What, and How?” In Humanitarianism in Question: Politics, Power, Ethics, edited by Michael Barnett and Thomas G. Weiss. Ithaca, N.Y.: Cornell University Press.

THAKUR, RAMESH. (2005) The United Nations, Peace and Security: From Collective Security to the Responsibility to Protect. Cambridge: Cambridge University Press.

THAKUR, RAMESH, AND WILLIAM MALEY. (1999) "The Ottawa Convention on Landmines: A Landmark Humanitarian Treaty in Arms Control?” Global Governance 5 (3): 273-302.

UNITED NATIONS. (2005) World Summit Outcome, UN General Assembly Resolution A/RES/60/1. New York: United Nations.

UNITED NATIONS. (2008) UN Action to Counter Terrorism, Helping Member States to Counter Terrorism. <http://www.un.org/terrorism/makingadifference.shtml> Accessed April 28, 2008.

UNITED NATIONS DEVELOPMENT PROGRAM (UNDP). (2007) Human Development Report 2007/2008: Fighting Climate Change: Human Solidarity in a Divided World. New York: Palgrave Macmillan.

WEISS, THOMAS G. (2007) Humanitarian Intervention: Ideas in Action. Cambridge, UK: Polity Press.

WEISS, THOMAS G., TATIANA CARAYANNIS, LOUIS EMMERIJ, AND RICHARD JOLLY. (2005) UN Voices: The Struggle for Development and Social Justice. UN Intellectual History Project. Bloomington: Indiana University Press.

WEISS, THOMAS G., TATIANA CARAYANNIS, AND RICHARD JOLLY. (2009) “The 'Third’ United Nations.” Global Governance 15(1): forthcoming. 
WORLD HEALTH ORGANIZATION (WHO). (2008) Fact Sheet/Smallpox.

<http://www.who.int/mediacentre/factsheets/smallpox/en/> Accessed July 31, 2008.

WURST, JIM. (April 1, 2004) “NGOs Criticize Nonproliferation Draft for Ignoring Disarmament.” U.N. Wire, www.unwire.org.

ZACHER, MARK, AND TANIA J. KEFFE. (2008) The Politics of Global Health Governance: United by Contagion. New York: Palgrave Macmillan. 